Check for updates

Cite this: RSC Adv., 2019, 9, 37537

Received 31st August 2019

Accepted 9th November 2019

DOI: 10.1039/c9ra06915a

rsc.li/rsc-advances

\section{A one-pot route for the synthesis of AuaPd/PMo 12 rGO as a dual functional electrocatalyst for ethanol electro-oxidation and hydrogen evolution reaction $\uparrow$}

\author{
Ali Ahmadpour, (D) *a Sara Khadempir, (D) *b Narges Ashraf, (D) ${ }^{c}$ Scott G. Mitchell (D) \\ and Mahdi $\mathrm{H}$. Ahangari ${ }^{\mathrm{a}}$
}

An in situ one-pot synthetic route for the synthesis of a $\mathrm{AuCPd} / \mathrm{PMO}_{12} /$ reduced graphene oxide ( $\mathrm{rGO}$ ) nanocomposite is presented, where the Keggin-type polyoxometalate phosphomolybdic acid $\left(\mathrm{PMO}_{12}\right)$ is used as both reducing and stabilizing agent. High-angle annular dark-field scanning transmission electron microscopy (HAADT-STEM), transmission electron microscopy (TEM), and $X$-ray diffraction analysis were applied to fully characterize the core-shell structure of Au@Pd/PMo 12 on the rGO matrix. Electrochemical studies showed how this nanocomposite acts as a dual electrocatalyst for the ethanol electro-oxidation reaction (EOR) and the hydrogen evolution reaction (HER). For the EOR, the Au@Pd/ $\mathrm{PMO}_{12} / \mathrm{rGO}$ electrocatalyst offers a low onset potential of $-0.77 \mathrm{~V} v \mathrm{vs}$. $\mathrm{Ag} / \mathrm{AgCl}$ and a high peak current density of $41 \mathrm{~mA} \mathrm{~cm}^{-2}$ in alkaline medium. This feature is discussed via detailed cyclic voltammetry (CV) studies illustrating how the superior performance of the synthetic nanocomposite could be attributed to the synergistic effect of $\mathrm{Au}, \mathrm{Pd}, \mathrm{PMO}_{12}$ and $\mathrm{rGO}$. Moreover, it has been confirmed that the proposed electrocatalyst exhibits low overpotentials for $10 \mathrm{~mA} \mathrm{~cm}{ }^{-2}$ current density $\left(\eta_{10}\right)$ in different pH media. The values of $\eta_{10}$ were $-109,300$ and $250 \mathrm{mV}$ vs. RHE in acidic, basic and neutral media, respectively. Also, the ability of the electrocatalyst to provide high HER current density and its remarkable stability have been confirmed.

\section{Introduction}

The demand for renewable and green energy resources has risen dramatically in recent years as the negative environmental impact of burning fossil fuels becomes evident. In this regard, small alcohols such as ethanol are currently regarded as some of the most eco-friendly and sustainable energy resources. For ethanol to be used as a fuel, it must be electro-oxidized in direct alcohol fuel cells (DAFCs) that are promising alternative power sources for future portable energy sources and vehicles because of their high energy conversion ability, low emission of pollutants, and low operating temperature. Nevertheless, making them available on the market depends on the innovation of

\footnotetext{
${ }^{a}$ Department of Chemical Engineering, Ferdowsi University of Mashhad, Mashhad, Iran.E-mail:ahmadpour@um.ac.ir

${ }^{b}$ Department of Chemical Engineering, Quchan University of Technology, Quchan, Iran. E-mail: s.khadempir@qiet.ac.ir

'Department of Chemistry, Faculty of Sciences, Ferdowsi University of Mashhad, Mashhad, Iran

${ }^{d}$ Instituto de Ciencia de Materiales de Aragón (ICMA-CSIC), CISC-Universidad de Zaragoza \& CIBER-BBN, 50009-Zaragoza, Spain

$\dagger$ Electronic supplementary information (ESI) available. See DOI: 10.1039/c9ra06915a
}

advanced electrocatalyst with excellent activity and durability at an acceptable cost.

On the other hand, hydrogen as a fuel for hydrogen fuel cells is currently viewed as an environment-friendly approach, particularly if derived as a product of a low-cost water splitting cell. Electrochemical hydrogen- and oxygen-evolution reactions are two combined half electrocatalytic reactions that take place in water splitting cells. ${ }^{1-3}$ Nearly all oxygen evolution reaction catalysts are designed for operation in neutral or alkaline media; whereas the most efficient hydrogen evolution reaction catalysts work in acidic media. Consequently, finding applicable catalysts that can simultaneously act over a wide range of $\mathrm{pH}$ range and for different reactions is necessary.

Nowadays, dual function (bifunctional) catalysts are routinely developed to promote two distinct electrochemical reactions and mechanisms. ${ }^{4-6}$ Although Pt containing catalysts are of significant interest for the Electrochemical Ethanol Oxidation Reaction (EOR) and Hydrogen Evolution Reaction (HER), its use as a commercial catalyst is limited by its high cost and low earth-abundancy. Pd-based catalytic materials, on the other hand, are viewed as alternative candidates due to their higher earth abundance, good catalytic activity, lower cost, and low poisoning compared with Pt. 
Recent studies have demonstrated that incorporating a second metal into Pd nanostructures, giving rise to bimetallic nanoparticles (NPs) such as AuPd, PdNi, PdAg, can significantly improve catalytic activity due to a synergetic effect between two combined metals. ${ }^{7-12}$ Among these bimetallic nanoparticles, AuPd NPs are of special interest because of their high catalytic activity. ${ }^{13-15}$ Currently, there are a number of synthetic procedures towards Pd-based bimetallic NPs such as co-reduction, seedmediated-growth in aqueous solution, electrodeposition, thermal decomposition, and galvanic replacement reaction. ${ }^{13-18}$ In addition to careful selection of NPs, immobilization on a conductive support improves their effective catalytic performance. Reduced graphene oxide (rGO) nanosheets are two-dimensional carbon materials which offer excellent support for dispersion of NPs, due to their large surface area, superior electronic mobility and thermal conductivity. ${ }^{19,20}$ It should be noted that embedding of presynthesized NPs on carbon substrate often causes agglomeration/aggregation therefore finding a direct method synthesis to bimetallic NPs on carbon support is favorable. ${ }^{15,21}$

Herein, we report a simple in situ one-pot synthesis of Au@Pd NPs supported on reduced graphene oxide. Precursors of Au and $\mathrm{Pd}$ and graphene oxide are simultaneously reduced in the same reaction medium using an anionic molecular metal-oxide a polyoxometalate (POM) - as a reducing and stabilizing agent. Structural analysis of the nanocomposites reveals an Au-core/Pdshell structure. The Au@Pd/PMo ${ }_{12} /$ rGO nanocomposites display a superior electrocatalytic activity for the HER over a wide range of $\mathrm{pH}$, and also act as an efficient electrocatalyst for EOR in alkaline media. Based on previous results ${ }^{21}$ and the data presented herein, our hypothesis is that the presence of Au promotes the synergetic catalytic activity performance of the Au@Pd/ $\mathrm{PMo}_{12} /$ rGO nanocomposites.

\section{Experimental section}

\section{Chemicals}

Palladium(II) chloride $\left(\mathrm{PdCl}_{2}\right)$, tetrachloroauric(III) acid trihydrate $\left(\mathrm{HAuCl}_{4} \cdot 3 \mathrm{H}_{2} \mathrm{O}\right)$, isopropyl alcohol $\left(\mathrm{C}_{2} \mathrm{H}_{6} \mathrm{OH}\right)$, graphite powder $(<50 \mathrm{~mm})$, potassium permanganate $\left(\mathrm{KMnO}_{4}\right)$, potassium persulfate $\left(\mathrm{K}_{2} \mathrm{~S}_{2} \mathrm{O}_{8}\right)$, phosphorus pentoxide $\left(\mathrm{P}_{2} \mathrm{O}_{5}\right)$, sodium nitrate $\left(\mathrm{NaNO}_{3}\right)$, hydrogen peroxide $\left(\mathrm{H}_{2} \mathrm{O}_{2}\right)$, sodium hydroxide $(\mathrm{NaOH})$, ethanol $\left(\mathrm{C}_{2} \mathrm{H}_{5} \mathrm{OH}\right)$, DMF ( $N, N$-dimethylformamide), sodium dihydrogen phosphate dihydrate $\left(\mathrm{NaH}_{2} \mathrm{PO}_{4} \cdot 2 \mathrm{H}_{2} \mathrm{O}\right)$, sulphuric acid $\left(\mathrm{H}_{2} \mathrm{SO}_{4}\right)$ and commercial $\mathrm{Pd} / \mathrm{C}(1 \mathrm{wt} \%$ metal loading) were purchased from Merck (Darmstadt, Germany). All chemicals were in analytical grade and used as received. Phosphomolybdic acid $\left(\mathrm{H}_{3} \mathrm{PMo}_{12} \mathrm{O}_{40}\right), 10 \mathrm{wt} \%$ of commercial Pt/C and Nafion@117 (5 wt\% in lower aliphatic alcohols and water) were obtained from Sigma-Aldrich. Al chemicals were in analytical grade and used as received. Phosphate buffer solution (PBS, $0.1 \mathrm{M}$ ) was made by dissolving the proper amount of $\mathrm{NaH}_{2} \mathrm{PO}_{4} \cdot 2 \mathrm{H}_{2} \mathrm{O}$ in deionized (DI) water and adjusting the $\mathrm{pH}$ to 7 by $0.1 \mathrm{M} \mathrm{NaOH}$ (aq) solution.

\section{Characterization}

Scanning electron microscopy (SEM) images were taken using a field emission SEM Inspect F50 with an EDX system INCA
PentaFETx3 (FEI Company, Eindhoven, Netherlands) in an energy range between $0-30 \mathrm{keV}$.

Transmission electron microscopy (TEM) was obtained by a FEI Tecnai T20 microscope operating at $200 \mathrm{kV}$. High-angle annular dark-field scanning TEM (HAADF-STEM) and STEM mapping were carried out using a Tecnai S-Twin30, $300 \mathrm{keV}$, GIF-TRIDIEM.

X-ray diffraction (XRD) studies were performed on X-ray diffractometer X'Pert Pro MPD $\left(\mathrm{Cu}-\mathrm{K}_{\alpha}\right.$ radiation, $40 \mathrm{kV}, 40$ $\mathrm{mA}, \lambda=1.54060 \AA$ )

The composition of the catalyst was examined with the help of inductively coupled plasma mass spectrometry (ICP-MS) by utilizing Agilent ICP-7900.

A $\mu$-Autolab type III electrochemical workstation with a threeelectrode cell was used to all electrochemical measurements.

\section{Synthesis of nanocomposites}

Graphene oxide (GO) was prepared based on modified Hummers' method as illustrated in our previous report. ${ }^{21}$ This process includes two chemical oxidation steps for converting the graphite powder to GO. GO was utilized as a matrix for sketching the $\mathrm{Au} @ \mathrm{Pd} / \mathrm{PMo}_{12} / \mathrm{rGO}$ and $\mathrm{Pd} / \mathrm{PMo}_{12} / \mathrm{rGO}$ nanocomposites; that were synthesized via the photocatalytic polyoxometalate assisted method. In a typical synthesis, $0.67 \mathrm{mg}$ $\mathrm{PdCl}_{2}, 1.6 \mathrm{mg} \mathrm{HAuCl} \cdot 3 \mathrm{H}_{2} \mathrm{O}$ and $27.4 \mathrm{mg} \mathrm{PMo}_{12}$ - as reducing and stabilizing agent-were added to $100 \mathrm{~mL}$ DI water and finally dissolved. Then, $10 \mathrm{~mL}$ of the as-prepared solution was transferred to a spectrophotometer cell, $480 \mu \mathrm{g}$ GO (20 wt $\%$ loading) was added to the mixture and ultrasonicated for $20 \mathrm{~min}$. Thereafter, $2 \mathrm{~mL}$ isopropyl alcohol-as sacrificial agent-were added and the entire reaction mixture was irradiated by a high pressure mercury vapour UV lamp (125 W) for $2 \mathrm{~h}$ under magnetic stirring. The $\mathrm{Au} @ \mathrm{Pd} / \mathrm{PMo}_{12} / \mathrm{rGO}$ nanocomposite was obtained after successive washing, centrifuging and drying process. The atomic ratio of Au to Pd was set to $(1: 1)$ and also, the amount of GO was adjusted based on the different loading of metal nanoparticles on GO $(10,20,30$ and $40 \mathrm{wt} \%)$. The Pd/ $\mathrm{PMo}_{12} / \mathrm{rGO}$ nanocomposite was produced with the same procedure without addition of $\mathrm{HAuCl}_{4} \cdot 3 \mathrm{H}_{2} \mathrm{O}$ salt solution.

\section{Working electrode preparation}

The catalyst ink was prepared by the following procedure: the proper amount of the as-prepared dried nanocomposite was dispersed in DI water to achieve the aqueous suspension of the catalyst ink $\left(1.0 \mathrm{mg} \mathrm{mL}^{-1}\right)$.

Glassy carbon electrode (GCE, $2 \mathrm{~mm}$ in diameter, Azar Electrode Co.) was used as working electrode which was pretreatment by surface polishing with $0.05 \mu \mathrm{m}$ alumina slurry, followed by ultrasonication in ethanol and then in water. To fabricate the modified GCE, $3 \mu \mathrm{L}$ of catalyst ink was drop casted on GCE and then dried at ambient temperature.

\section{Electrochemical measurements}

The HER and EOR were performed by a three-electrode cell with the saturated $\mathrm{Ag} / \mathrm{AgCl}$ electrode (Azar Electrode Co.) as the reference electrode, platinum wire (Azar Electrode Co.) as the 
counter electrode and coated glassy carbon electrode (GCE) was applied as working electrode. The EOR activity of the modified GCE electrodes with the as-prepared electrocatalysts was studied by making cyclic voltammogram (CV) measurements at a scan rate of $50 \mathrm{mV} \mathrm{s}^{-1}$ in a mixed solution of $1 \mathrm{M}$ ethanol and $1 \mathrm{M} \mathrm{NaOH}(\mathrm{aq})$ as the electrolyte at room temperature. Electrochemical impedance spectroscopy (EIS) was recorded using Ivium Stat (US) with an AC voltage amplitude of $50 \mathrm{mV}$ by scanning frequency from $100 \mathrm{kHz}$ to $10 \mathrm{~Hz}$. The studies of HER were acquired by linear sweep voltammetry (LSV) experiments which was carried out at the scan rate of $50 \mathrm{mV} \mathrm{s}^{-1}$ in an electrolyte solution of $0.5 \mathrm{M} \mathrm{H}_{2} \mathrm{SO}_{4}(\mathrm{pH} 0.3), 1.0 \mathrm{M} \mathrm{NaOH}(\mathrm{pH}$ 14) and 0.1 M PBS (pH 7). The LSV results were reported with respect to the reversible hydrogen electrode (RHE) potential, which was described by the following equation:

$$
E_{\mathrm{RHE}}=E_{\mathrm{Ag} / \mathrm{AgCl}}+0.059 \times \mathrm{pH}+0.197
$$

\section{Results and discussion}

\section{Structural analysis}

NPs distribution and surface structure of $20 \mathrm{wt} \%$ loading of Au@Pd NPs on rGO were analyzed by HAADF-STEM, TEM and SEM. The corresponding low-magnification HAADF-STEM and TEM images confirm the uniform dispersion of the NPs on GNSs (Fig. 1). Moreover, high-magnification HAADF-STEM (Fig. 2) of the as-prepared nanocomposite shows a clear contrast between the heavier and the lighter elements in the NPs that demonstrate the Au core-Pd shell nanostructure with an average size of $13 \mathrm{~nm}$. The spherical Au cores possess an average diameter of $4 \mathrm{~nm}$ and are surrounded by $4 \mathrm{~nm}$ thick Pd shells.

EDS elemental analysis maps and EDS spectra (Fig. 3) show $\mathrm{Au}$ atoms are mainly located in the center of the particles whereas Pd atoms are comprised a complete shell around the core, whenever a minor Au population are visible in the shell.

The Mo from the $\mathrm{PMo}_{12}$ was found entirely covering the crystalline NPs providing evidence for their stabilizing role.

The exact composition of Au@Pd NPs was identified to be $\mathrm{Au}_{41} \mathrm{Pd}_{59}$ (atomic ratio of $\mathrm{Au}: \mathrm{Pd}=1: 1$ in precursor) by ICP-MS
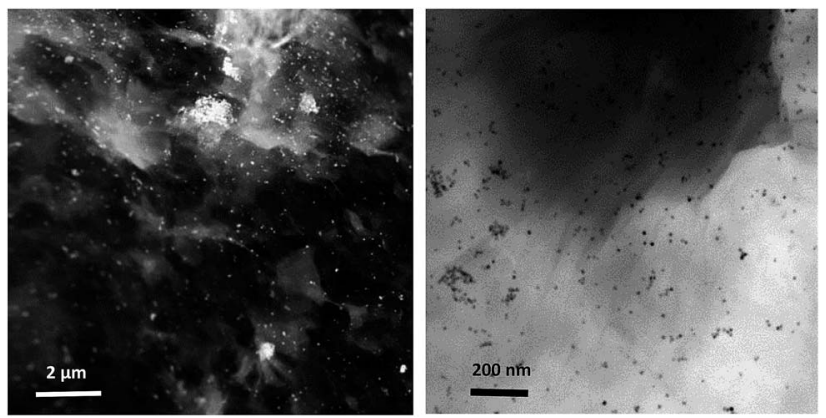

Fig. 1 HAADF-STEM (left) and TEM (right) images of AuAPd/PMo ${ }_{12} /$ rGO.
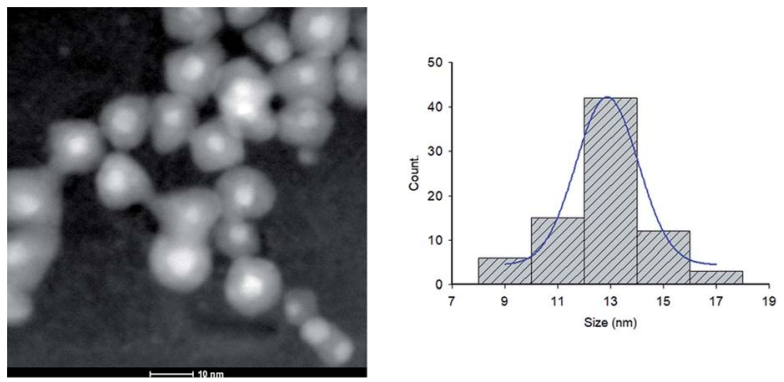

Fig. 2 High magnification HAADF-STEM image and the corresponding size distribution histogram of $\mathrm{Au} \mathrm{aPd} / \mathrm{PMO}_{12} / \mathrm{rGO}$ nanohybrid.

analysis. Also the total metal loading on GO was found (18.7 wt\%) which is closed to the initial metal loading ( $20 \mathrm{wt} \%$ ).

The crystalline nature of the Au@Pd NPs and simultaneous reduction of the as-made GO into $\mathrm{rGO}$ can be verified by XRD analysis. Fig. 4 (XRD pattern of the GO) shows the existence of diffraction peak at $10.22^{\circ}\left(8.65^{\circ} \mathrm{A}\right.$ interlayer $d$-spacing $)$ inferred the successful oxidation via the intercalation of the oxygencontaining functional groups in the interlayer of graphite powder and their exfoliation. ${ }^{22-25}$ When the Au@Pd NPs or Pd NPs were loaded onto the graphene surfaces, the sharp peak at $10.22^{\circ}$ vanished turning into a broader peak at around $20-30^{\circ}$, meaning that the graphitic nature was reconstructed by the $\mathrm{PMO}_{12}$ simultaneous reduction process. In addition, the $\mathrm{Au} @ \mathrm{Pd} / \mathrm{PMo}_{12} / \mathrm{rGO}$ pattern shows well-separated reflection peaks in (1 111$)$ and $\left(\begin{array}{lll}2 & 0 & 0\end{array}\right)$ planes and nearly unclear peaks in $(2$ $20)$ plane attributing to crystalline fcc structure for both of Pd and $\mathrm{Au}$ elements, which represents additional confirmation that Au@Pd NPs include a bimetallic core-shell structure and do not involve a homogenous bimetallic alloy. ${ }^{16,18,26}$

Furthermore, the Pd ( $\left.\begin{array}{lll}1 & 1 & 1\end{array}\right)$ peak shifted $c a .0 .3^{\circ}$ to lower two theta angle with respect to the Pd (1 1 1 1) peak position in the Pd/ $\mathrm{PMo}_{12} / \mathrm{rGO}$ pattern $\left(40.172^{\circ}\right.$ to $39.84^{\circ}$, corresponding to a $d$ spacing change from $2.240 \AA$ to $2.260 \AA$ ) which indicates a $0.88 \%$ lattice expansion. Such phenomena in bimetallic systems have been referred to the "strain effect" that originates
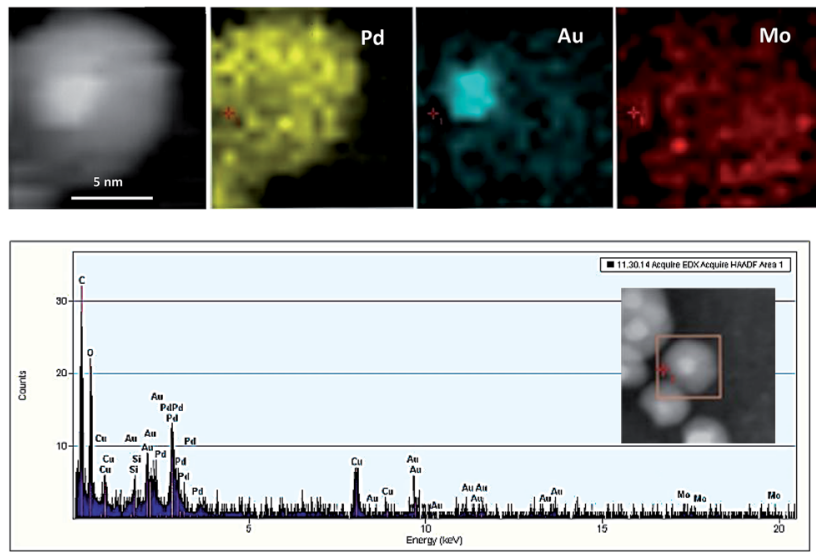

Fig. 3 EDS elemental mapping of AuaPd/PMo ${ }_{12} / \mathrm{rGO}$ and accompanying EDS spectrum. 


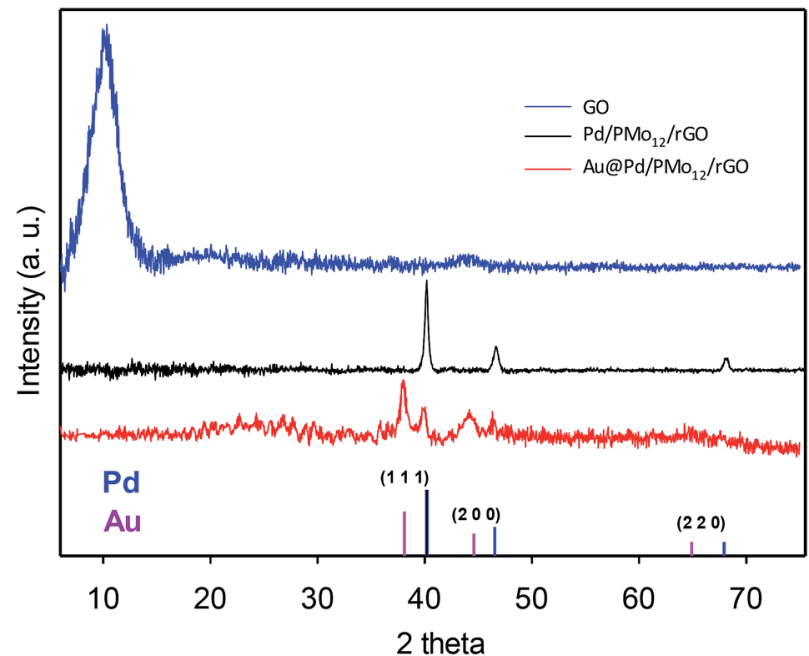

Fig. 4 XRD pattern of $\mathrm{GO}, \mathrm{Pd} / \mathrm{PMO}_{12} / \mathrm{rGO}$ and $\mathrm{Au}\left(\mathrm{Pd} / \mathrm{PMO} \mathrm{O}_{12} / \mathrm{rGO}\right.$. A standard XRD pattern of $\mathrm{Pd}$ and $\mathrm{Au}$ is given.

from the substantial lattice mismatch and interaction between two neighboring metals..$^{18,26-28}$ Although an intact Pd shell is assembled, the $\mathrm{Au}$ core atoms are able to stretch the Pd atomic shell making the surface electronic structure different from the monometallic and unstrained Pd. This property can be favorable for EOR, as discussed later. ${ }^{29-31}$ Moreover, there are no visible diffraction peaks of the $\mathrm{PMo}_{12}$, inferring highly dispersed amorphous $\mathrm{PMo}_{12}$ in the nanocomposite structure.

Another experiment was conducted to further check the presence of $\mathrm{PMo}_{12}$ in the $\mathrm{Au} @ \mathrm{Pd} / \mathrm{PMo}_{12} / \mathrm{rGO}$ nano-structure. Since $\mathrm{PMo}_{12}$ are hydrolyzed in pure aqueous solvent, the cyclic voltammetry behavior of $\mathrm{PMo}_{12}$ and $\mathrm{Au} @ \mathrm{Pd} / \mathrm{PMo}_{12} / \mathrm{rGO}$ were investigated in $50 \% \mathrm{v} / \mathrm{v}$ water : DMF solution containing $0.5 \mathrm{M} \mathrm{H}_{2} \mathrm{SO}_{4}$ as an electrolyte.

It should be considered that $\mathrm{PMo}_{12}$ can undergo a multielectron reversible redox process without losing its integrity. ${ }^{32-35}$ By comparing the CVs of $\mathrm{PMo}_{12}, \mathrm{Pd} / \mathrm{PMo}_{12} / \mathrm{rGO}$ and $\mathrm{Au} @ \mathrm{Pd} / \mathrm{PMo}_{12} / \mathrm{rGO}$ (Fig. 5), it can be inferred that the cathodic voltammetric peaks in the forward scan at $c a .0 .31$ and $0.19 \mathrm{~V}$ in $\mathrm{Pd} / \mathrm{PMo}_{12} / \mathrm{rGO}$ and $\mathrm{Au} @ \mathrm{Pd} / \mathrm{PMo}_{12} / \mathrm{rGO}$ electrode should be originated from the characteristic redox behavior of $\mathrm{PMo}_{12}$ and verifies that $\mathrm{PMo}_{12}$ is adsorbed on Pd during the synthesis of the nanohybrides (inset in Fig. 5). The other characteristic peaks of $\mathrm{PMo}_{12}$ overlap by hydrogen evolution region.

\section{EOR analysis}

In an effort to evaluate the electrocatalytic activity of the asprepared nanocomposite, a series of $\mathrm{CV}$ and $\mathrm{CA}$ experiments were carried out in $1 \mathrm{M} \mathrm{NaOH}$ and $1 \mathrm{M} \mathrm{NaOH}+1 \mathrm{M}$ ethanol solution. The electrochemical behavior of $\mathrm{Au} @ \mathrm{Pd} / \mathrm{PMo}_{12} / \mathrm{rGO}$ in aqueous $1 \mathrm{M} \mathrm{NaOH}$ solution as supporting electrolyte is shown in Fig. 6. For comparison, the $\mathrm{CV}$ response of $\mathrm{Pd} / \mathrm{PMo}_{12} /$ rGO is also given. Different potential regions can be recognized for the $\mathrm{Au} @ \mathrm{Pd} / \mathrm{PMo}_{12} / \mathrm{rGO}$ nanocomposite, which indicates different electrochemical processes occurring on the surface of the electrocatalyst. ${ }^{29}$ During the forward scan; the potential

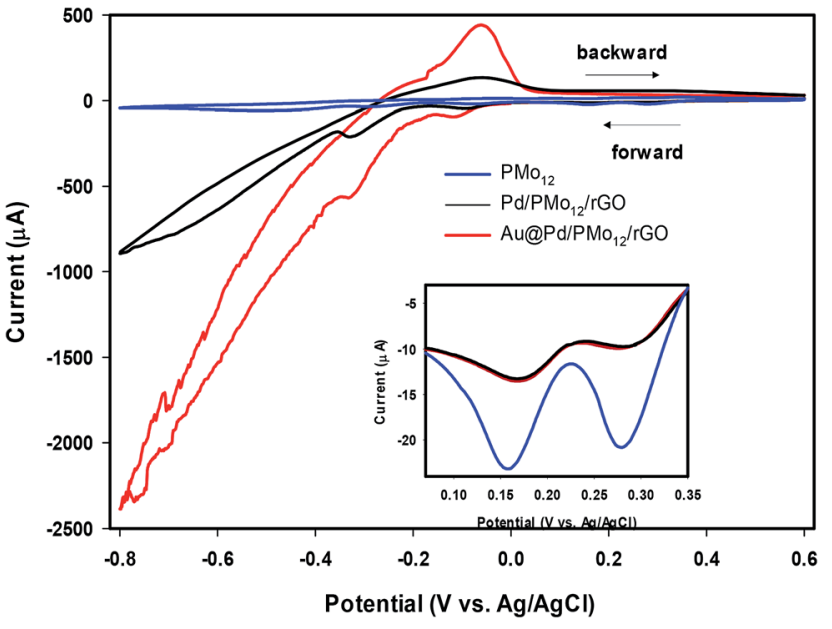

Fig. 5 Cyclic voltammograms (CVs) of Au@Pd/PMo $12 / \mathrm{rGO}, \mathrm{Pd} / \mathrm{PMO}_{12} /$ $\mathrm{rGO}$ and pure $\mathrm{PMo}_{12}$ in $50 \%(\mathrm{v} / \mathrm{v})$ water-DMF solution containing $0.5 \mathrm{M}$ $\mathrm{H}_{2} \mathrm{SO}_{4}$.

region between $-0.8 \mathrm{~V}$ and $-0.35 \mathrm{~V} v s$. $\mathrm{Ag} / \mathrm{AgCl}$ is ascribed to $\mathrm{OH}^{-}$ion adsorption on Pd to form oxygen-containing species $\left(\mathrm{Pd}-\mathrm{OH}_{\mathrm{ads}}\right)$ which is partially overlapped by the hydrogen desorption process. Another potential area emerged at $-0.35 \mathrm{~V}$ corresponding to Pd oxidation to its metal oxide on the catalyst surface. Clearly, a single reduction peak at $c a .-0.3 \mathrm{~V}$ in the backward scan associated to the Pd oxide reduction. ${ }^{14,36-38}$ Fig. $\mathrm{S} 1$ and $\mathrm{S} 2 \uparrow$ show the $\mathrm{CV}$ responses towards EOR and TEM images of different Au@Pd NPs loading on GO (10, 20, 30 and $40 \mathrm{wt} \%$ loading). Based on these results, EOR was boosted by increasing metal loading till $20 \mathrm{wt} \%$ loading and then decreased with further loading via the agglomeration process, so more experiments were done on 20 wt $\%$ loading of Au@Pd/ $\mathrm{PMo}_{12} / \mathrm{rGO}$. Fig. 7 shows the CV responses of the $20 \mathrm{wt} \%$ loading of $\mathrm{Au} @ \mathrm{Pd} / \mathrm{PMo}_{12} / \mathrm{rGO}$ during EOR. Also, the $\mathrm{CV}$ responses of $\mathrm{Pd} / \mathrm{PMO}_{12} / \mathrm{rGO}$ as well as commercial $\mathrm{Pd} / \mathrm{C}$ are included for the purpose of comparison. It is notable that based on our previous results, $\mathrm{Pd} / \mathrm{PMo}_{12} / \mathrm{rGO}$ exhibited remarkable catalytic activity toward EOR in $1 \mathrm{M} \mathrm{NaOH}$.

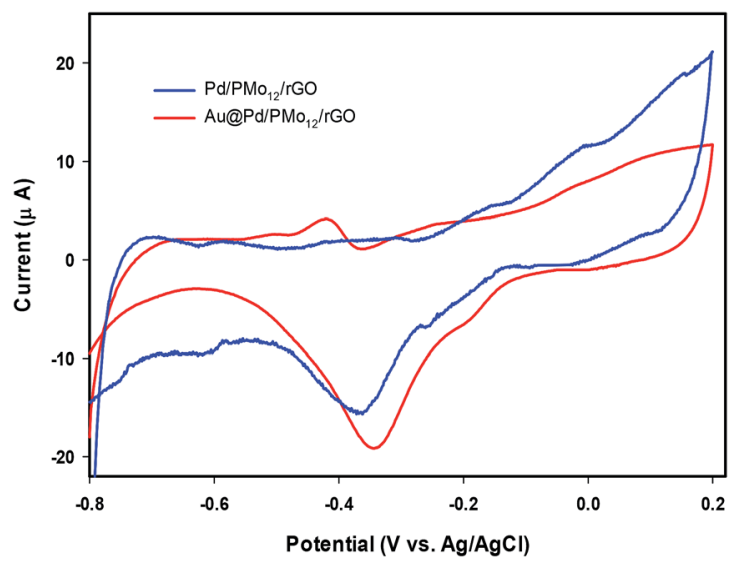

Fig. $6 \mathrm{CV}$ of $\mathrm{Au} \mathrm{aPd} / \mathrm{PMO}_{12} / \mathrm{rGO}$ and $\mathrm{Pd} / \mathrm{PMO}_{12} / \mathrm{rGO}$ in $1 \mathrm{M} \mathrm{NaOH}$ solution at a scan rate of $50 \mathrm{mV} \mathrm{s}{ }^{-1}$. 


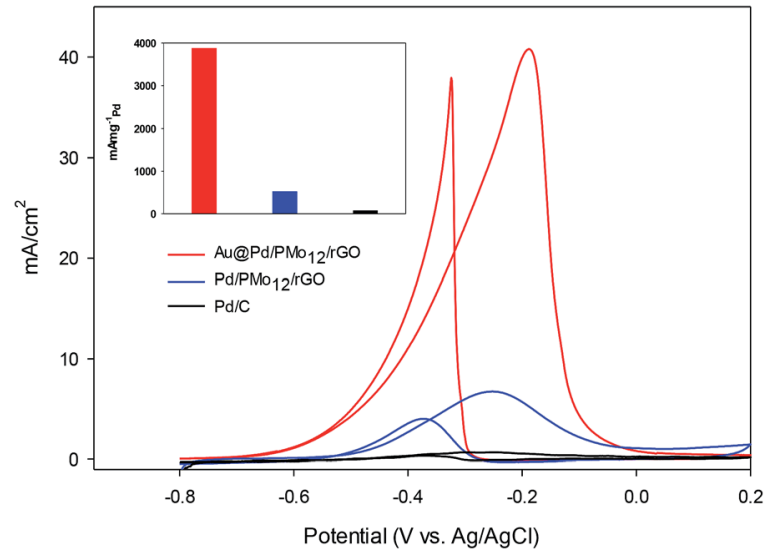

Fig. $7 \mathrm{CV}$ curves for $\mathrm{Au}\left(\mathrm{Pd} / \mathrm{PMO}_{12} / \mathrm{rGO}\right.$ and $\mathrm{Pd} / \mathrm{PMO}{ }_{12} / \mathrm{rGO}$ and $\mathrm{Pd} / \mathrm{C}$ in $1 \mathrm{M} \mathrm{NaOH}+1 \mathrm{M}$ ethanol at a scan rate of $50 \mathrm{mV} \mathrm{s}^{-1}$.

The strong oxidation peaks in the positive sweep with $E_{\mathrm{p}}$ at ca. $-0.19 \mathrm{~V}$ for $\mathrm{Au} @ \mathrm{Pd} / \mathrm{PMo}_{12} / \mathrm{rGO}$ and $c a$. $-0.25 \mathrm{~V}$ for $\mathrm{Pd} /$ $\mathrm{PMo}_{12} / \mathrm{rGO}$ represent the ability of both Pd-based electrocatalysts towards EOR. As can be seen, the current density of $\mathrm{Au} @ \mathrm{Pd} / \mathrm{PMo}_{12} / \mathrm{rGO}$ is considerably higher than that seen for $\mathrm{Pd} /$ $\mathrm{PMo}_{12} / \mathrm{rGO}\left(i_{\mathrm{p}} \sim 41\right.$ vs. $\left.7 \mathrm{~mA} \mathrm{~cm}{ }^{-2}\right)$. The onset potential for $\mathrm{Au} @ \mathrm{Pd} / \mathrm{PMo}_{12} / \mathrm{rGO}$ is observed at $c a .-0.77 \mathrm{~V}$ that shifts to more positive potentials $(\mathrm{ca}$. $-0.65 \mathrm{~V})$ for $\mathrm{Pd} / \mathrm{PMo}_{12} / \mathrm{rGO}$. In the reverse scan, another oxidation process also occurred that corresponds to the irreversible EOR. It should be noted that the onset potential of the reverse peak is near to the onset potential for the reduction of $\mathrm{Pd}$ oxide in $1 \mathrm{M} \mathrm{NaOH}$ supporting electrolyte mentioned in Fig. 6.

The electrochemical stability of the as-prepared nanocomposites is examined by chronoamperometry measurement $(j-t)$ at a fixed potential of $-0.3 \mathrm{~V}$ versus $\mathrm{Ag} / \mathrm{AgCl}$ in $1 \mathrm{M} \mathrm{NaOH}+$ $1 \mathrm{M}$ ethanol solution (Fig. 8). It is clear that the current drops is slower on the $\mathrm{Au} @ \mathrm{Pd} / \mathrm{PMo}_{12} / \mathrm{rGO}$ than on the $\mathrm{Pd} / \mathrm{PMo}_{12} / \mathrm{rGO}$ and $\mathrm{Pd} / \mathrm{C}$ electrodes which was associated to the poisoning of the electrode by intermediate species. The result show that core@shell structure of $\mathrm{Au}$ and Pd can improve not only the superior electrocatalytic activity but also the electrocatalytic stability toward EOR. The electrochemical surface area (ECSA) was calculated based on the columbic charge collected during the reduction region of Pd oxide to Pd (see Fig. 6) by considering that the charge consumption for monolayer of Pd oxide reduction is $405 \mu \mathrm{C} \mathrm{cm}^{-2}$; and then corrected to the mass of Pd that used for electrode fabrication. Eqn (1) shows the ECSA formula: ${ }^{39}$

$$
\operatorname{ECSA}\left(\mathrm{cm}^{2} \mathrm{~g}^{-1}\right)=\frac{Q_{\text {measured }}(\mu \mathrm{C})}{Q_{\text {monolayer }}\left(\mu \mathrm{C} \mathrm{cm}^{-2}\right) \times \text { mass } \text { Pd electrode }(\mathrm{g})}
$$

The estimated ECSA for the Au@Pd/PMo ${ }_{12} / \mathrm{rGO}$ and Pd/PMo ${ }_{12} /$ rGO were 56 and $38 \mathrm{~m}^{2} \mathrm{~g}_{\mathrm{Pd}}{ }^{-1}$, respectively. As a consequence, the 1.45-fold increase in ECSA is mostly attributed to bimetallic Au@Pd NPs, because the distribution and carrier effect of graphene are the same in each of the two electrocatalysts.

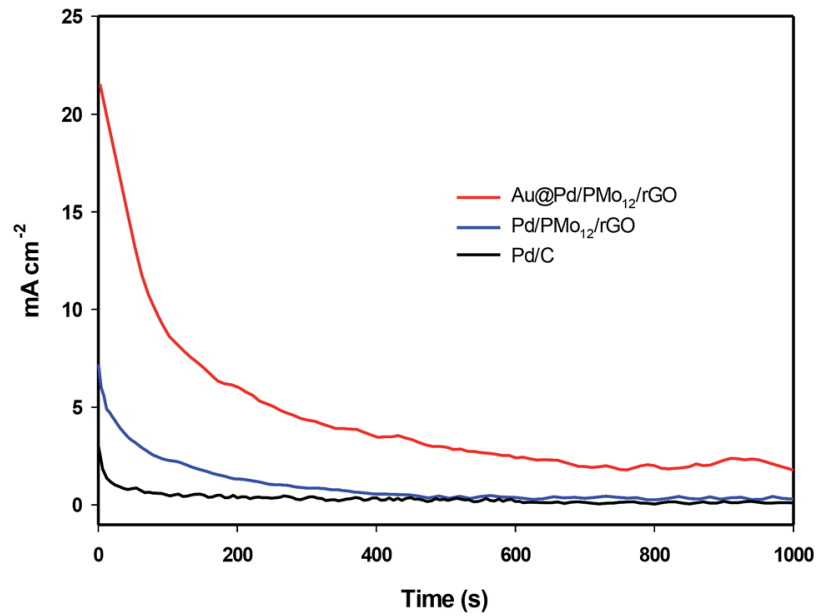

Fig. 8 Chronoamperograms of $\mathrm{Au}\left(\mathrm{Pd} / \mathrm{PMO}_{12} / \mathrm{rGO}\right.$ and $\mathrm{Pd} / \mathrm{PMo}_{12} /$ $\mathrm{rGO}$ and $\mathrm{Pd} / \mathrm{C}$ in at $-0.3 \mathrm{~V}$ in $1 \mathrm{M} \mathrm{NaOH}+1 \mathrm{M}$ ethanol solution.

The remaining section is focused on the probable reasons for the remarkable catalytic activity of the $\mathrm{Au} @ \mathrm{Pd} / \mathrm{PMo}_{12} / \mathrm{rGO}$ nanocomposite. For this purpose, the EOR mechanism that discussed in the literatures is presented in the following equations. ${ }^{37,38}$

$$
\begin{gathered}
\mathrm{Pd}+\mathrm{CH}_{3} \mathrm{CH}_{2} \mathrm{OH} \leftrightarrow \mathrm{Pd}-\left(\mathrm{CH}_{3} \mathrm{CH}_{2} \mathrm{OH}\right)_{\mathrm{ads}} \\
\mathrm{Pd}-\left(\mathrm{CH}_{3} \mathrm{CH}_{2} \mathrm{OH}\right)_{\mathrm{ads}}+3 \mathrm{OH}^{-} \rightarrow \begin{array}{c}
\mathrm{Pd}-\left(\mathrm{CH}_{3} \mathrm{CO}\right)_{\mathrm{ads}}+3 \mathrm{H}_{2} \mathrm{O} \\
+3 e^{-}
\end{array} \\
\mathrm{Pd}-\left(\mathrm{CH}_{3} \mathrm{CO}\right)_{\mathrm{ads}}+\mathrm{Pd}-\mathrm{OH}_{\mathrm{ads}} \rightarrow \mathrm{Pd}-\mathrm{CH}_{3} \mathrm{COOH}+\mathrm{Pd} \\
\mathrm{Pd}-\mathrm{CH}_{3} \mathrm{COOH}+\mathrm{OH}^{-} \rightarrow \mathrm{Pd}+\mathrm{CH}_{3} \mathrm{COO}^{-}+\mathrm{H}_{2} \mathrm{O}
\end{gathered}
$$

It is revealed that the ethanol was adsorbed in the initial potential region and turned into the resultant ethoxy groups at the surface of Pd (eqn (2) and (3)). Eqn (4) points out the stripping off the Pd surfaces by $\mathrm{Pd}-\mathrm{OH}_{\mathrm{ads}}$ and eqn (5) involves the fast releasing of the acetate as the major product. It is worth noting that among the entire process, eqn (4) is the ratedetermining step meaning that any strategies that facilitate the formation and effective coverage of $\mathrm{CH}_{3} \mathrm{CO}_{\mathrm{ads}}$ and $\mathrm{OH}_{\mathrm{ads}}$ species on the surface of catalyst can promote the EOR. ${ }^{35,37,38}$

Based on this mechanism, one reason for improved catalytic activity of the $\mathrm{Au} @ \mathrm{Pd} / \mathrm{PMo}_{12} / \mathrm{rGO}$ could be due to the geometric "strain effect" observed from the XRD data. It is entirely possible that the Au core atoms can modify the surface electronic structure of $\mathrm{Pd}$ and thereby can enhance the adsorption of $\mathrm{OH}_{\text {ads }}$ on Pd surface and accelerate the dissociative adsorption of ethanol on $\mathrm{Au} @ \mathrm{Pd} / \mathrm{PMo}_{12} / \mathrm{rGO}$ electrocatalyst via eqn (5). Moreover, the ligand effect - the heterometallic bonding interaction between $\mathrm{Pd}$ and $\mathrm{Au}$ - may further influence the superior catalytic activity of the $\mathrm{Au} @ \mathrm{Pd} / \mathrm{PMo}_{12} / \mathrm{rGO}^{29,40-42} \mathrm{All}$ of the above reasons can justify the negative shift in the onset potential EOR and also higher current density of $\mathrm{Au} @ \mathrm{Pd} / \mathrm{PMo}_{12} / \mathrm{rGO}$ compared to the unstrained $\mathrm{Pd}$ in $\mathrm{Pd} / \mathrm{PMo}_{12} / \mathrm{rGO}$ electrocatalyst. 
Another reason for better catalytic activity of the nanocomposite could be related to lower poisoning effect. Based on the EOR mechanism, poisoning effect which originates from Pd oxide formation, can block the active sites of the electrocatalyst. The presence of Au confers a delay in Pd oxide formation. Fig. 9, indicates the CVs of the $\mathrm{Au} @ \mathrm{Pd} / \mathrm{PMo}_{12} / \mathrm{rGO}$ and $\mathrm{Pd} / \mathrm{PMo}_{12} / \mathrm{rGO}$ in $1 \mathrm{M} \mathrm{NaOH}$ electrolyte. It shows that the Pd oxide formation is slowed significantly in the $\mathrm{Au} @ \mathrm{Pd} / \mathrm{PMo}_{12} / \mathrm{rGO}$ compared to the $\mathrm{Pd} / \mathrm{PMo}_{12} / \mathrm{rGO}$ electrocatalyst. The results confirm that fortunately the poisoning effect of the oxide formation can be manipulated by incorporation of the second metal and the $\mathrm{Au} @ \mathrm{Pd} / \mathrm{PMo}_{12} / \mathrm{rGO}$ structure can inhibit the Pd oxide formation which leads to improved EOR.

In order to probe the electrochemical charge transfer properties of the electrocatalyst, the EIS technique was applied. In general, the Nyquist plot is related to the charge transfer resistance $\left(R_{\mathrm{ct}}\right)$ of the electrochemical reaction in high frequency region and Warburg impedance in low frequency zone. ${ }^{4-45}$ Fig. 10 represents the Nyquist plots of the Au@Pd/ $\mathrm{PMo}_{12} / \mathrm{rGO}$ and $\mathrm{Pd} / \mathrm{PMo}_{12} / \mathrm{rGO}$ to evaluate the kinetics of electrocatalyst in EOR. In both plots, the semicircular zone is not well defined leading to a dominance of the Warburg impedance over the whole available range. So, the system is kinetically facile and mass transfer plays a role in EOR.

The Randles equivalent circuit (inset in Fig. 10) was fitted based on the EIS data, which contains the elements of: ohmic solution resistance $\left(R_{\mathrm{S}}\right)$, Warburg impedance $\left(Z_{\mathrm{W}}\right),\left(R_{\mathrm{ct}}\right)$ and double layer capacitance $\left(C_{\mathrm{dl}}\right) \cdot{ }^{46,47}$ According to this equivalent circuit, the calculated $R_{\mathrm{ct}}$ for $\mathrm{Au} @ \mathrm{Pd} / \mathrm{PMo}_{12} / \mathrm{rGO}$ and $\mathrm{Pd} / \mathrm{PMo}_{12} /$ rGO electrodes are $773 \Omega \mathrm{cm}^{2}$ and $1270 \Omega \mathrm{cm}^{2}$, respectively. It is noted that the same $R_{\mathrm{s}}=33 \Omega$ was calculated. The higher charge transfer rate demonstrating that the EOR was more kinetically facile on the $\mathrm{Au} @ \mathrm{Pd} / \mathrm{PMo}_{12} / \mathrm{rGO}$ electrode than on the $\mathrm{Pd} /$ $\mathrm{PMo}_{12} / \mathrm{rGO}$ which is attributed to the interaction between two neighbouring metals in Au@Pd nanostructure.

It should be noted that the electrocatalytic experiments were performed in alkaline media and $\mathrm{PMo}_{12}$ may decompose at this $\mathrm{pH} ;^{\mathbf{3 4 4 8 , 4 9}}$ however, no significant effect on the catalytic activity of the Au@Pd/PMo ${ }_{12} /$ rGO was observed, even following several runs.

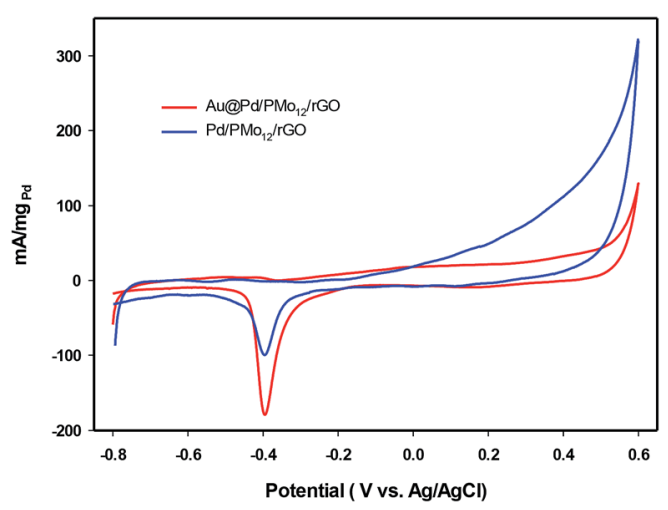

Fig. $9 \mathrm{CV}$ curves for Au@Pd/PMo $12 / \mathrm{rGO}$ and $\mathrm{Pd} / \mathrm{PMO}_{12} / \mathrm{rGO}$ in $1 \mathrm{M}$ $\mathrm{NaOH}$ at a scan rate of $50 \mathrm{mV} \mathrm{s}^{-1}$.

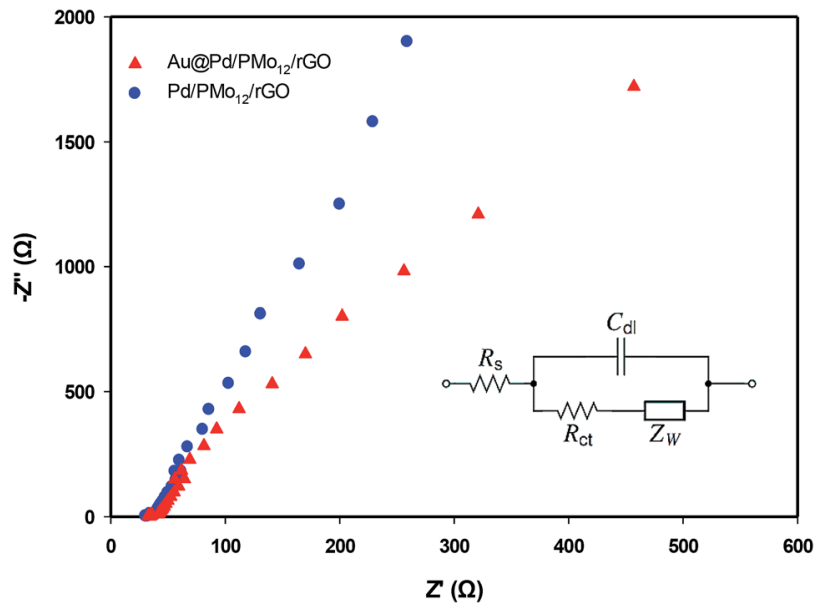

Fig. 10 Nyquist plots of EOR on the Au@Pd/PMo $12 / \mathrm{rGO}$ and $\mathrm{Pd} /$ $\mathrm{PMO}_{12} / \mathrm{rGO}$ electrodes in $1 \mathrm{M} \mathrm{NaOH}+1 \mathrm{M}$ ethanol solution at $-0.17 \mathrm{~V}$ vs. $\mathrm{Ag} / \mathrm{AgCl}$; inset is an equivalent Randles circuit.

\section{HER study}

The HER performance of electrocatalysts commonly examined by LSV method which is displayed as the current density (normalized to the surface area of the GCE) versus applied potential.

The overall HER in acidic medium is

$$
2 \mathrm{H}_{3} \mathrm{O}^{+}+2 e^{-} \rightarrow \mathrm{H}_{2}+2 \mathrm{H}_{2} \mathrm{O}
$$

and in neutral or basic solution is

$$
2 \mathrm{H}_{2} \mathrm{O}+2 e^{-} \rightarrow \mathrm{H}_{2}+2 \mathrm{OH}^{-}
$$

Although the kinetics of HER in neutral medium are slower than in acidic or basic media in principle, neutral HER is of interest in commercial scale hydrogen production because of the gentle reaction condition and stability against corrosion, oxidation etc $^{\mathbf{1 , 5 0 , 5 1}}$. The LSV curves for the as-prepared Au@Pd/ $\mathrm{PMo}_{12} / \mathrm{rGO}, \mathrm{Pd} / \mathrm{PMo}_{12} / \mathrm{rGO}$ and $\mathrm{PMo}_{12} / \mathrm{rGO}$ nanocomposites at different $\mathrm{pH}$ values are shown in Fig. 11a-e. For comparison purposes, the HER activity of commercial $\mathrm{Pt} / \mathrm{C}$ were also evaluated. The reason why $\mathrm{Pt} / \mathrm{C}$ was selected instead of pure $\mathrm{Pt}$ electrode is that the $\mathrm{Pt}$ has a similar catalytic activity with $\mathrm{Pt} / \mathrm{C}$ in acidic medium, but it has a much lower activity than $\mathrm{Pt} / \mathrm{C}$ in neutral and basic media which is because Pt is a bulk catalyst, whereas $\mathrm{Pt} / \mathrm{C}$ contains $\mathrm{Pt}$ nanoparticles as catalyst. Fig. 11a shows the LSV curves under acidic condition $\left(0.5 \mathrm{M} \mathrm{H}_{2} \mathrm{SO}_{4}, \mathrm{pH}\right.$ $0.3)$. Here, the required overpotential for $10 \mathrm{~mA} \mathrm{~cm}{ }^{-2}$ current density $\left(\eta_{10}\right)$ is considered as the criterion for comparing HER electrocatalytic activity. The $\mathrm{Au} @ \mathrm{Pd} / \mathrm{PMo}_{12} / \mathrm{rGO}$ shows much lower $\eta_{10}\left(-109 \mathrm{mV}\right.$ vs. RHE) than that of $\mathrm{Pd} / \mathrm{PMo}_{12} / \mathrm{rGO}$ $(-295 \mathrm{mV} v s$. RHE) and near to that of Pt/C (-80 mV vs. RHE). Furthermore, it is very interesting that the proposed electrocatalyst is able to carry large current densities of more than 500 $\mathrm{mA} \mathrm{cm}^{-2}$ for HER. These evidences manifest that the HER 

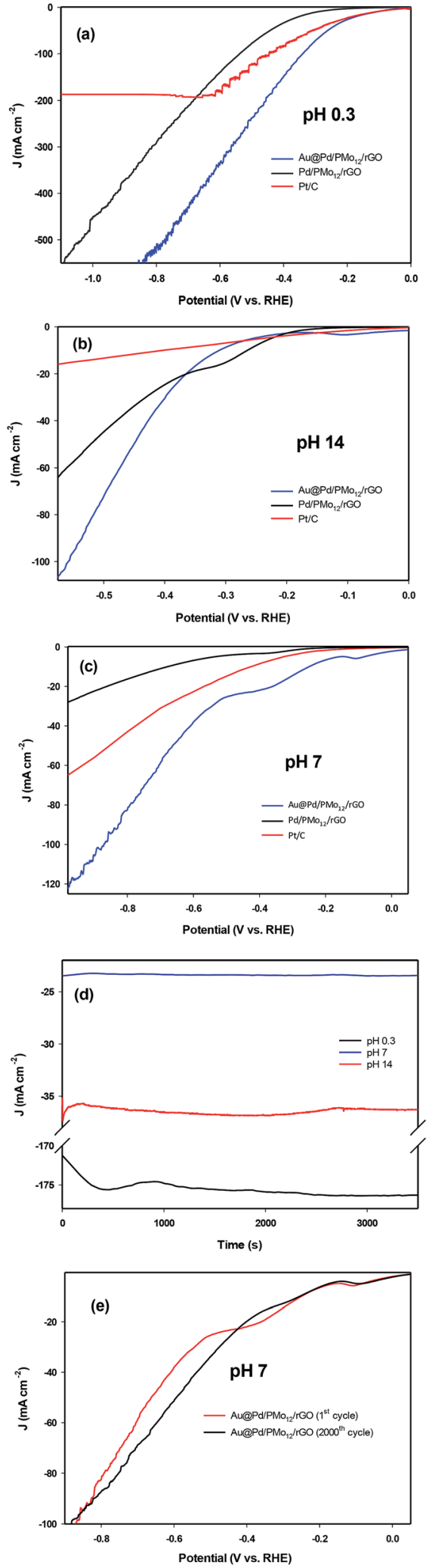

Fig. 11 LSV curves (scan rate $50 \mathrm{mV} \mathrm{s}^{-1}$ ) in (a) $0.5 \mathrm{M} \mathrm{H}_{2} \mathrm{SO}_{4}(\mathrm{pH} \mathrm{0.3),} \mathrm{(b)}$ $1 \mathrm{M} \mathrm{NaOH}$ (pH 14), (c) $0.1 \mathrm{M} \mathrm{PBS}$ ( $\mathrm{pH}$ 7), (d) chronoamperograms of Au@ $\mathrm{Pd} / \mathrm{PMO}_{12} / \mathrm{rGO}$ at $-0.4 \mathrm{~V}$ (RHE) in different $\mathrm{pH}$ media, (e) $0.1 \mathrm{M}$ PBS $(\mathrm{pH} 7)$ on Au@Pd/PMo $12 / \mathrm{rGO}$ in first cycle and after 2000 cycles. kinetics on $\mathrm{Au} @ \mathrm{Pd} / \mathrm{PMo}_{12} / \mathrm{rGO}$ is very fast compared to $\mathrm{Pd} /$ $\mathrm{PMo}_{12} / \mathrm{rGO}$, showing its excellent electrocatalytic activity.

Fig. 11b represents the LSV curves in basic medium (1 M $\mathrm{NaOH})$. The Au@Pd/PMo $/ 2 / \mathrm{rGO}$ shows a boosted electrocatalytic activity; as the $\eta_{10}$ of $\mathrm{Pd} / \mathrm{PMo}_{12} / \mathrm{rGO}$ is $280 \mathrm{mV}$ ( $v s$. RHE) which is lower than that of $\mathrm{Au} @ \mathrm{Pd} / \mathrm{PMo}_{12} / \mathrm{rGO}$ (300 mV vs. RHE) and $\mathrm{Pt} / \mathrm{C}$ (401 mV vs. RHE). But, the $\mathrm{Au} @ \mathrm{Pd} / \mathrm{PMo}_{12} / \mathrm{rGO}$ delivers greatly higher current density (more than $120 \mathrm{~mA} \mathrm{~cm}{ }^{-2}$ ) compared to $\mathrm{Pd} / \mathrm{PMo}_{12} / \mathrm{rGO}$ and $\mathrm{Pt} / \mathrm{C}$ which means the greater catalytic performance of $\mathrm{Au} @ \mathrm{Pd} / \mathrm{PMo}_{12} / \mathrm{rGO}$.

Fig. 11c shows the LSVs curves in neutral solution (PBS, $0.1 \mathrm{M}$, surprisingly, the $\mathrm{Au} @ \mathrm{Pd} / \mathrm{PMo}_{12} / \mathrm{rGO}$ electrocatalyst needs only $250 \mathrm{mV}$ (vs. RHE) overpotential to drive $10 \mathrm{~mA} \mathrm{~cm}{ }^{-2}$ whereas the $\mathrm{Pt} / \mathrm{C}$ and $\mathrm{Pd} / \mathrm{PMo}_{12} / \mathrm{rGO}$ takeover 430 and $677 \mathrm{mV}$ (vs. RHE), respectively. Fig. 11d presents the stability of HER on the Au@Pd/ $\mathrm{PMO}_{12} / \mathrm{rGO}$ electrocatalyst under a fixed potential of $-0.4 \mathrm{~V}$ ( $v$. $\mathrm{RHE}$ ) at $\mathrm{pH}=0.3,7$ and 14 . The time depended current density curves show that the current densities were almost unchanged at $\mathrm{pH} 7$ and 14 during the $3600 \mathrm{~s}$ chronoamperometric test. Furthermore, at $\mathrm{pH} 0.3$, the current density was increased within the first $2500 \mathrm{~s}$ and then it remains nearly constant.

Since the activity of electrocatalyst was very important in neutral solution, the durability of the electrocatalyst was explored by using continuous LSV scans in 0.1 M PBS. As represented in Fig. 11e the $\mathrm{Au} @ \mathrm{Pd} / \mathrm{PMo}_{12} / \mathrm{rGO}$ electrocatalyst maintains a comparable performance to the first cycle after 2000 cycles, such that there is only $1.6 \%$ increase in $\eta_{10}$; suggesting an excellent durability in neutral solution. All of the above evidences revealed that the $\mathrm{Au} @ \mathrm{Pd} / \mathrm{PMo}_{12} / \mathrm{rGO}$ is an efficient electrocatalyst for HER.

\section{Conclusions}

To sum up, Au@Pd NP-decorated rGO was synthesized using $\mathrm{PMO}_{12}$ as both reducing and stabilizing agent. The core@shell structure of the Au@Pd has been confirmed by TEM, XRD, HAADF-STEM imaging and EDS elemental mapping. The superior electrocatalytic behavior of the $\mathrm{Au} @ \mathrm{Pd} / \mathrm{PMo}_{12} / \mathrm{rGo}$ compared to $\mathrm{Pd} / \mathrm{PMo}_{12} / \mathrm{rGo}$ towards EOR was proved by electrochemical methods. The enhanced performance could be attributed to the incorporation of Au core resulting from: (1) geometric "strain effect" (lattice mismatch) and ligand effect that facilitate $\mathrm{OH}^{-}$adsorption on Pd (2) limiting the PdO formation (3) higher ECSA. Also, the HER electrocatalytic performances of $\mathrm{Au} @ \mathrm{Pd} / \mathrm{PMo}_{12} / \mathrm{rGo}$ in acidic, alkaline and neutral media were demonstrated. The proposed electrocatalyst exhibits remarkably high activity when compared to the commercial $\mathrm{Pt} / \mathrm{C}$ and $\mathrm{Pd} / \mathrm{PMo}_{12} / \mathrm{rGo}$.

\section{Conflicts of interest}

There are no conflicts to declare.

\section{Acknowledgements}

Financial support by Fundación General CSIC (S.G.M., Programa ComFuturo), Fondo Social Europeo-Gobierno de Aragón 
and CIBER-BBN is gratefully acknowledged. The authors gratefully acknowledge The Advanced Microscopy Laboratory (University of Zaragoza). Also, the authors would like to thank Ms Z. Dabirifar and Mr A. Kardan for their help with the electrochemical measurements.

\section{Notes and references}

1 X. Zou, X. Huang, A. Goswami, R. Silva, B. R. Sathe, E. Mikmeková and T. J. A. C. I. E. Asefa, Angew. Chem., Int. Ed., 2014, 53, 4372-4376.

2 X. Yang, A. Banerjee and R. Ahuja, Catal. Sci. Technol., 2019, 9, 4981-4989.

3 C. Xu, C. Jin, W. Chang, X. Hu, H. Deng, E. Liu and J. Fan, Catal. Sci. Technol., 2019, 9, 4990-5000.

4 J. Bao, J. Wang, Y. Zhou, Y. Hu, Z. Zhang, T. Li, Y. Xue, C. Guo and Y. Zhang, Catal. Sci. Technol., 2019, 9, 4961-4969.

5 H. Begum, M. S. Ahmed and S. Jeon, ACS Appl. Mater. Interfaces, 2017, 9, 39303-39311.

6 R. K. Pandey and V. Lakshminarayanan, J. Phys. Chem. C, 2010, 114, 8507-8514.

7 Y. Shu, X. Shi, Y. Ji, Y. Wen, X. Guo, Y. Ying, Y. Wu and H. Yang, ACS Appl. Mater. Interfaces, 2018, 10, 4743-4749.

8 J. Guo, R. Chen, F. C. Zhu, S. G. Sun and H. M. Villullas, Appl. Catal., B, 2018, 224, 602-611.

9 Z. Qi, H. Geng, X. Wang, C. Zhao, H. Ji, C. Zhang, J. Xu and Z. Zhang, J. Power Sources, 2011, 196, 5823-5828.

10 J. Davoodi and M. Ahmadi, Composites, Part B, 2012, 43, 1014.

11 A. Laghrissi and M. Es-Souni, Catal. Sci. Technol., 2019, 9, 4355-4364.

12 S. Xu, J. Zhang, J. Wang, L. Lv, Y. Sun, X. Huang, T. Lin, X. Huang and L. Shao, Catal. Sci. Technol., 2019, 9, 12551259.

13 A. Laghrissi and M. Es-Souni, Int. J. Hydrogen Energy, 2019, 44, 14918-14926.

14 A. N. Geraldes, D. F. Da Silva, E. S. Pino, J. C. M. Da Silva, R. F. B. De Souza, P. Hammer, E. V. Spinacé, A. O. Neto, M. Linardi and M. C. Dos Santos, Electrochim. Acta, 2013, 111, 455-465.

15 Y. Yang, L. Jin, B. Liu, P. Kerns and J. He, Electrochim. Acta, 2018, 269, 441-451.

16 C. W. Yang, K. Chanda, P. H. Lin, Y. N. Wang, C. W. Liao and M. H. Huang, J. Am. Chem. Soc., 2011, 133, 19993-20000.

17 J. Xu, T. Zhao, S. Shen and Y. Li, Int. J. Hydrogen Energy, 2010, 35, 6490-6500.

18 C. Y. Chiu, M. Y. Yang, F. C. Lin, J. S. Huang and M. H. Huang, Nanoscale, 2014, 6, 7656-7665.

19 F. Wang, J. Qiao, J. Wang, H. Wu, X. Yue, Z. Wang, W. Sun and K. Sun, Electrochim. Acta, 2018, 271, 1-9.

20 N. Alfi, M. Z. Yazdan-Abad, A. Rezvani, M. Noroozifar and M. Khorasani-Motlagh, J. Power Sources, 2018, 396, 742-748.

21 S. Khadempir, A. Ahmadpour, M. T. H. Mosavian, N. Ashraf, F. F. Bamoharram, S. G. Mitchell and M. Jesús, $R S C A d v$, 2015, 5, 24319-24326.

22 F. Shaheen, M. Hammad Aziz, M. Fakhar-e-Alam, M. Atif, M. Fatima, R. Ahmad, A. Hanif, S. Anwar, F. Zafar,
G. Abbas, S. Ali and M. Ahmed, Nanomaterials, 2017, 7, 401-418.

23 A. H. Wazir and I. W. Kundi, J. Chem. Soc. Pak., 2016, 38, 1116.

24 C. N. Yeh, K. Raidongia, J. Shao, Q. H. Yang and J. Huang, Nat. Chem., 2015, 7, 166-170.

25 Y. Zhao, W. Ran, J. He, Y. Huang, Z. Liu, W. Liu, Y. Tang, L. Zhang, D. Gao and F. Gao, Small, 2015, 11, 1310-1319.

26 C. H. Kuo, L. K. Lamontagne, C. N. Brodsky, L. Y. Chou, J. Zhuang, B. T. Sneed, M. K. Sheehan and C. K. Tsung, ChemSusChem, 2013, 6, 1993-2000.

27 D. Chen, J. Li, P. Cui, H. Liu and J. Yang, J. Mater. Chem. A, 2016, 4, 3813-3821.

28 P. Strasser, S. Koh, T. Anniyev, J. Greeley, K. More, C. Yu, Z. Liu, S. Kaya, D. Nordlund and H. Ogasawara, Nat. Chem., 2010, 2, 454-460.

29 Y. H. Qin, Y. Li, R. L. Lv, T. L. Wang, W. G. Wang and C. W. Wang, Electrochim. Acta, 2014, 144, 50-55.

30 P. C. Su, H. S. Chen, T. Y. Chen, C. W. Liu, C. H. Lee, J. F. Lee, T. S. Chan and K. W. Wang, Int. J. Hydrogen Energy, 2013, 38, 4474-4482.

31 C. L. Lu, K. S. Prasad, H. L. Wu, J. a. A. Ho and M. H. Huang, J. Am. Chem. Soc., 2010, 132, 14546-14553.

32 E. Itabashi, Bull. Chem. Soc. Jpn., 1987, 60, 1333-1336.

33 J. Chen, S. Liu, W. Feng, G. Zhang and F. Yang, Phys. Chem. Chem. Phys., 2013, 15, 5664-5669.

34 M. Sadakane and E. Steckhan, Chem. Rev., 1998, 98, 219-238. 35 S. Khadempir, A. Ahmadpour, M. T. H. Mosavian, N. Ashraf, F. F. Bamoharram, R. Fernández-Pacheco, M. Jesús and S. G. Mitchell, RSC Adv., 2016, 6, 5359-5366.

36 Q. He, W. Chen, S. Mukerjee, S. Chen and F. Laufek, J. Power Sources, 2009, 187, 298-304.

37 Z. Liang, T. Zhao, J. Xu and L. Zhu, Electrochim. Acta, 2009, 54, 2203-2208.

38 J. Yin, S. Shan, M. S. Ng, L. Yang, D. Mott, W. Fang, N. Kang, J. Luo and C. J. Zhong, Langmuir, 2013, 29, 9249-9258.

39 M. Farsadrooh, J. Torrero, L. Pascual, M. A. Peña, M. Retuerto and S. Rojas, Appl. Catal., B, 2018, 237, 866-875.

40 Y. Wang, T. S. Nguyen, X. Liu and X. Wang, J. Power Sources, 2010, 195, 2619-2622.

41 F. Gao and D. W. Goodman, Chem. Soc. Rev., 2012, 41, 80098020.

42 D. Ferrer, A. Torres-Castro, X. Gao, S. Sepulveda-Guzman, U. Ortiz-Mendez and M. Jose-Yacaman, Nano Lett., 2007, 7, 1701-1705.

43 A. J. Bard, L. R. Faulkner, J. Leddy and C. G. Zoski, Electrochemical methods: fundamentals and applications, Wiley New York, 1980.

44 Y. Feng, K. Zhang, B. Yan, S. Li and Y. Du, Catalysts, 2016, 6, 103.

45 E. Hatami, N. Ashraf and M. H. Arbab-Zavar, J. Electrochem. Soc., 2019, 166, B1379-B1386.

46 F. Tehrani, L. Reiner and B. Bavarian, PLoS One, 2015, 10, 0145036.

47 Y. Jalit, M. Moreno, F. A. Gutierrez, A. Sanchez Arribas, M. Chicharro, E. Bermejo, A. Zapardiel, C. Parrado, 
G. A. Rivas and M. C. Rodríguez, Electroanalysis, 2013, 25, 1116-1121.

48 R. Liu, X. Yu, G. Zhang, S. Zhang, H. Cao, A. Dolbecq, P. Mialane, B. Keita and L. Zhi, J. Mater. Chem. A, 2013, 1, 11961-11969.

49 R. Liu, S. Li, X. Yu, G. Zhang, Y. Ma and J. Yao, J. Mater. Chem., 2011, 21, 14917-14924.
50 W. Sheng, H. A. Gasteiger and Y. Shao-Horn, J. Electrochem. Soc., 2010, 157, B1529-B1536.

51 Y. W. Peng, C. Shan, H. J. Wang, L. Y. Hong, S. Yao, R. J. Wu, Z. M. Zhang and T. B. Lu, Adv. Energy Mater., 2019, 9, 1900597. 